\title{
FEATURES OF MASTERING THE PROGRAM MATERIAL CONTENT BY FUTURE PHYSICAL EDUCATION SPECIALISTS
}

\author{
Khomenko Irina ${ }^{1}$ \\ Kuzmina Katerina ${ }^{2}$
}

DOI: https://doi.org/10.30525/978-9934-571-89-3_74

The process of mastering the content of the program material by future specialists of physical culture is complex, contradictory and multi-phased. On the basis of the analysis of psychological and pedagogical researches of certain aspects of control and analytical competence of physical education teachers, our own theoretical search it was revealed that professional knowledge serves as the basis for the highest form of human knowledge - professional speech and thinking. In this context, the mastering of the program material content includes:

- mastering of the conceptual-terminology subsystem of professional disciplines;

- vocational and terminological literacy in oral and written speech;

- ability to conduct conversation, persuade, prove, admire ideas and plans, that is to solve communication problems in situations of professional communication.

However, without taking into account all the nuances of worldview and pedagogical aspects, selecting and optimizing the mastering of the program material content through its logical structuring, it is impossible to manage rationally the development of the investigated competence of physical education teachers.

The purposeful mastering of the program material content by students actually links the goals, program material content, teaching, learning, educational microenvironment, which ensures the integrity of the implementation of control and analytical competence of physical education teachers. According to the results of the theoretical analysis of the problem, it can be approved that the mastering of the content of the program material should be regulated by general didactic principles (scientific knowledge, conscious learning, systematic and consistent learning, the strength of knowledge acquisition, an individual approach to students), as well as the

${ }^{1}$ Bohdan Khmelnytsky National University of Cherkasy, Ukraine

${ }^{2}$ Bohdan Khmelnytsky National University of Cherkasy, Ukraine 
specific principles of learning (interdisciplinarity, orientation to future professional activity).

It should be noted that the principle of scientific knowledge envisages enriching the vocabulary of students with professional vocabulary, which is related to the scientific style of speech and term creation. The science of learning consists in the mastering of the adequate content of each term and semantic distinction by students, in correct scientific explanation and mastering the methods of terminology.

Implementation of the conscious learning principle of program material involves the construction of experimental techniques based on the unity of speech development, language and thinking, words and concepts, scientific concepts and terms. The processes of conscious studying the terms directly interfere with the influence of various factors on the formation of speech skills and also such skills, where under interference the violation of one language norm under the influence of another language norm is understood. In this case, as a rule, the external interference (the influence of other languages) and internal (the effect of similar elements on each other within the same language) is distinguished. Apart from that, the interference at the level of speech and language level is differentiated :

- a random similar coincidence in the sound of the concept of foreign-language origin and Ukrainian, which do not have a common origin (yes, in such a way or e.g., instead of "bilirubin" - from lat. Bilirubin - yellow pigment - they write "bilorubin", instead of "iron-defeciency" - "iron deficiency");

- a random coincidence in the sound with another notion of foreign origin (the interchange of the termoelement of the neuro (Greek: neuron - the nerve) and the nephro - (Greek: nephros - the kidney).

It is clear that such coincidences may lead to an incorrect, distorted understanding of the professional term semantics. This type of error may be due to the incorrect morpheme classification, which is the most complicated, since it requires a fairly thorough knowledge of the classical languages. During the investigation, we discovered that quite a large number of students do not know the semantics of professional terms and terminology of foreign origin. Only a conscious approach (and the mechanical learning of terms is difficult to say) can prevent errors. For this purpose, it is proposed to clarify the etymology (origin) of a professional term, to establish its foreign language etymon, to define semantics, and to divide it into morphemes.

The principle of systematic and sequential learning is conditioned by the logic of science and the peculiarities of the cognitive activity of students of physical culture disciplines. It is important for them to use the terms not isolated from each other, but in a complex. This should be taken into account in the texts of exercises, in which it is necessary to submit the material on the basis of semantic, lexical-grammatical, word-building and stylistic features.

As a result of scientific research, a specific norm is distinguished, the observance of which facilitates optimization of the mastering of the program material content by future specialists of physical culture through its logical structuring. Thus, the principle of interdisciplinarity of all professional knowledge gained during the study of general 
and vocational training disciplines provides their systematization [1], which would aim to teach and educate competent professionals. Note that till today, in the domestic theory and methodology of education management there was not produced or ... the domestic theory didn't produce ... an unified view of interpersonal relations. Some scholars interpret them as a didactic principle (M. Levin, N. Loshkarev, V. Maksimov, S. Rashkov), others as didactic (V. Khomutsky, V. Fedorov, V. Maksimov, A. Usov, M. Cherkes-Zade) or pedagogical (F. Sokolov) condition.

From the review of the scientific and pedagogical literature [4;5], it is known that interpersonal relationships are classified by the type of knowledge and by the type of activity. At the level of knowledge, they are revealed through language, theory or applied part. The implementation of such links at the level of activities is achieved through a variety of learning methods and organizational forms. Based on totality of the structure of educational subjects and the structure of the educational process, some scholars distinguish content-information, operational-activity and organizationalmethodical connections. It is not coincidentally, that according to V. Semichenko, "each academic discipline forms the future specialists' professional qualities of the three levels of integration: intro-subject (knowledge, skills and skills that make up the specifics of a particular field of science), inter-subject (interdisciplinary, formed by a common cause-consequential influence of the complexes of educational disciplines) and metasubject (integrative qualities that are formed as a result of the influence of the whole system of vocational training)" [5, p. 40].

The principle of orientation to future professional activities provides mastering the knowledge, competencies and skills necessary for a future specialist since the first lessons. This principle is revealed in the fact that the mastering of the program material content is conditioned by the vital need, an attempt to continuously improve the student's speech, enriching their vocabulary depending on the specializationof the preparation [2, p. 17]. In this way, the mastering of the program material content in the course of educational activities is gradually transformed into a professional one, passing a number of transitional forms. Such logic of training future specialists provides the implementation of physical education teachers control and analytical competence for the thorough mastering of students theoretical vocational and terminological knowledge, the formation of practical skills and skills during the logical structuring of the content of the program material.

Modern professional training of future physical culture spesialists is characterized by improvement of curricula, programs, qualification standards and training itself. It should be noted that the issues of selection and structuring of the program material contents, which is studied at the faculties of physical culture, were studied by A. Demin, P. Luzan, V. Manko, I. Palamar, S. Daukilas [3; 4] and other scholars. In their works the principles of selection and optimization of the mastering of the program material content are substantiated, the knowledge, abilities and skills which the future specialist must possess are analyzed and the approaches to logical structuring and presentation of this material are revealed [2]. Taking into account the requirements of the present, with selecting and structuring of the program material content, researchers turn to the activity approach $[2 ; 3]$, focusing on the professional 
activity of a future specialist through the selection of professionally directed educational information and a set of tasks and exercises that maximally cover all elements of future professional activities.

So, selecting and structuring the program material one should take into account the relevant principles and criteria.

\section{References:}

1. Borovska O. (2003). Spivvidnoshennja nacionaljnykh ta internacionaljnykh terminiv $\mathrm{v}$ ukrajinsjkij terminologhiji sfery fizychnoji kuljtury ta sportu [The Value of National and International Terms in the Ukrainian Terminology of the Sphere of Physical Culture and Spectrum]. Young sports science of Ukraine: collection of scientific works on the field of physical culture and sports, vol. 7, no. 1, pp. 35-40.

2. Hercyk M. S. Vaceba O.M. (2005). Vstup do specialjnostej ghaluzi "Fizychne vykhovannja i sport" [Introduction to the specialties of the branch "Physical education and sports"]. Kharkiv: OVS, 240 p. (in Ukrainian)

3. Djomin A. I., Luzan P. Gh., Djomin O. A. (1999). Teoretychni i metodychni osnovy formuvannja vminj ta navychok profesijnoji terminologhiji [Theoretical and methodical foundations of forming skills and skills of professional terminology]. Pedagogics and psychology of professional education, no. 3, pp. 51-62.

4. Luzan P. Gh. (1999). Aktyvizacija navchannja studentiv [Enhancing student learning]. Kiev, 216 p. (in Ukrainian)

5. Semychenko V. A. (1996).Vykorystannja psykhologhiji v navchaljno-vykhovnomu procesi vyshhoji shkoly [The use of psychology in the educational process of higher education]. Pedagogics and psychology, no. 3, pp. 40-41. 